\title{
Homonormativity and Celebrating Diversity: Australian School Staff Involvement in Gay-Straight Alliances.
}

Ruby Grant1*

Kim Beasy2

Bianca Coleman2

1 School of Social Sciences, University of Tasmania

2 Faculty of Education, University of Tasmania

*Corresponding Author: Ruby Grant, School of Social Sciences, University of Tasmania, Private Bag 22, Hobart, Tasmania 7001, Australia. Telephone: +61 36226 1556. Email: rfgrant@utas.edu.au

Funding: This work was supported by the University of Tasmania Creativity, Culture and Society Research Development Program.

\section{Author Biographies:}

Ruby Grant is an Associate Lecturer in Sociology at the University of Tasmania. Her research and teaching interests include feminist theory, queer studies, and LGBTI health. Ruby tweets at: @ notoriousrfg. ORCiD: 0000-0003-3007-0168.

Kim Beasy is an Education Lecturer specialising in Equity and Diversity at the University of Tasmania. Her research and teaching passions include inclusive education, education for sustainability and all things social theory. Kim tweets at: @kim_beasy. ORCiD: 0000-0002-5998-1419

Bianca Coleman is an Associate Lecturer in Humanities and Social Sciences Education at the University of Tasmania. Bianca's research interests include geography education, technology education and teacher education. Bianca tweets at: @Bianca_JColeman. ORCiD: 0000-0003-0373-2269 


\title{
Homonormativity and Celebrating Diversity: Australian School Staff Involvement in Gay-Straight Alliances.
}

\begin{abstract}
With the growing acceptance and normalisation of same-sex attraction in the West, scholars from a range of fields have documented a "post-gay" shift, or a decline in the significance of sexual identity labels among youth. Despite this shift, lesbian, gay, bisexual, transgender, intersex and queer (LGBTIQ) youth continue to experience discrimination and harassment, particularly in schools. In this context, this article examines the role of student gay-straight alliances (GSA) or 'diversity groups' in Australian schools. Most research on GSAs focuses on student experiences in the North American context. In contrast, this article provides a unique exploration of teachers and staff involvement in school GSAs in Tasmania, Australia. Drawing on qualitative interviews with teachers and staff, this article examines staff perceptions and involvement in GSAs and the impact this may have on GSA function and success. Through thematic analysis, we identify three common situations: active GSAs, inactive GSAs, and singular event-based initiatives. We argue that neoliberal and homonormative understandings of LGBTIQ-inclusion permeate staff approaches to facilitating GSAs and impact on the potential for these groups to undertake the critical political work needed to bring about change in school contexts.
\end{abstract}

Keywords: gay-straight alliance, inclusive education, post gay, student activism, teachers

\section{Introduction}

Over the last three decades, increasing acceptance of homosexuality in the West has seen shifts in law reform extending greater rights to same-sex couples and a broader normalisation of sexuality and gender diversity. Some scholars argue that since the 1990s we have entered a "post-gay" era where sexuality is becoming a less significant identity marker, especially for youth (see Adams et al. 2014; Coleman-Fountain 2014; Savin-Williams 2004). However, despite this growing normalisation and acceptance 
of same-sex attraction, lesbian, gay, bisexual, transgender, intersex and queer (LGBTIQ) youth continue to experience discrimination and harassment, particularly in schools (Jones et al. 2016; Robinson et al. 2014). Furthermore, as Kampler and Connell (2018) outline, post-gay debates are now being called into question as LGBTIQ rights are facing renewed resistance with the rise of the alt-right, religiousright, and other conservative populism internationally. In this context, this article will explore the role of school gay-straight alliances (GSA) in Australia, with particular focus on school staff perceptions and involvement in these groups.

Australian and international research consistently indicates that inclusive school cultures improve the educational outcomes and health and wellbeing of LGBTIQ students (Jones and Hillier 2013; Kosciw et al. 2013; Robinson and Ferfolja 2002; Shannon 2016). School is one of the most commonly reported sites where LGBTIQ youth experience physical and verbal abuse, discrimination, and social exclusion (Hillier et al. 2010; Robinson et al. 2014). While the majority of this harassment and/or discrimination is perpetrated by peers, teachers and school staff can also explicitly and implicitly reinforce homophobia, biphobia, and transphobia through failing to address these behaviours (Dragowski et al. 2016). Subsequently, there is now a growing body of interdisciplinary research identifying the need for LGBTIQinclusive schooling environments.

We acknowledge that the term inclusive education, which we employ throughout this paper, is problematic. As Rasmussen (2006) maintains, inclusive education is an "oxymoronic organising concept" (p. 46). First, it holds that if schools were truly inclusive of LGBTI students, there would be little need for specifically designed educational practices, such as the GSAs we describe in this paper, to support students and provide them with 'safe spaces' in schools. Second, the term is widely used within educational discourses to refer to varied school practices employed to support students with diverse educational needs (such as, students with physical and intellectual disabilities, students from racial and ethnic minority backgrounds, students with diverse sexual identities, and students with academic, sporting and/or musical gifts and talents, amongst others (Baak, 2019; Faas, Smith \& Darmody, 2018; Grant et al., 2018; Slee, 2001; Stevens \& Wurf, 2018)) and, therefore, lacks specificity for explaining educational practices that focus on LGBTI students. Finally, 
the various practices employed in schools to 'include' LGBTI students can potentially serve to isolate these students, marginalise them and trivialise their sexual identities. Schools have consistently been found to sites for the reproduction of heteronormativity (Čeplak, 2013; Gansen, 2017). School practices that are meant to be LGBTI-inclusive, for example, 'celebration days' like Wear It Purple Day and Harmony Day (Beasy \& Grant 2018), may inadvertently 'other' (Elia \& Eliason, 2010) LGBTI-identifying students by drawing attention to their sexual identities, which they may or may not want to publicly share (Toynton, 2006). While we acknowledge the problematic nature of this language, we nonetheless have used the term 'inclusive education' to describe school-based practices designed to support LGBTI students. First, there is precedent for using this language within existing literature about the experiences of LGBTI students (see Flores, 2012; Ward, 2017), and, second, our participants (practicing teachers and school support staff) repeatedly used the term to describe their own practices.

According to Sadowski $(2016,9)$, one of the most common features of LGBTIQinclusive schools is the presence of a LGBTIQ student support group or GSA. GSAs are extracurricular student groups or clubs that aim to provide a safe space within schools for LGBTIQ students and their heterosexual allies (Porta et al. 2017, 490). The majority of literature examining the role of GSAs in fostering inclusive school cultures focuses on North American high schools. Canada and the United States have a well-established history of LGBTIQ student activism, with the earliest GSAs being founded in the late 1980s (Beemyn 2003; Peter et al. 2015). Most research on GSAs examines student experiences of GSA membership and the impact of GSAs on LGBTIQ student experiences at school. Comparatively few studies examine teachers and school staff roles in GSAs (for exception, see Swanson and Gettinger 2015). In contrast to North America, school-based GSAs are a less-established practice in Australia. Reflecting this, there is a dearth of Australian research exploring the impact of LGBTIQ student groups on school cultures (for an exception, see Waling and Roffee 2018). The majority of Australian LGBTIQ-inclusive education scholarship focuses on student experiences (Jones et al. 2016; Shannon 2016), staff capabilities (Ferfolja 2007; Grant et al. 2018), teacher education (Ferfolja and Robinson 2004), and policy frameworks (Jones et al. 2016). 
To address this literature gap, in this article we examine teachers and school staff engagement with GSAs (or equivalent LGBTIQ student groups) in state government secondary schools in Tasmania, Australia. Given the dearth of Australian research on GSAs, we explore teachers' understandings of the role of these groups in schools and how these ideas shape staff perceptions of their schools as inclusive spaces. Drawing on Ghaziani's (2011) examination of post-gay discourse in US LGBTIQ student politics, in this article we will analyse the extent to which Tasmanian school staff reproduce post-gay, or, "homonormative" (see Duggan 2002) understandings of sexuality, through their perceptions of and involvement in GSAs. In doing so, this research seeks to make unique empirical and theoretical contributions to Australian sexuality studies and inclusive education scholarship.

\section{Literature Review: Gay-Straight Alliances}

International research shows that LGBTIQ students in schools where GSAs are present report feeling safer and more accepted regardless of whether they are involved in the group (Clarke and MacDougall 2012; Fetner et al. 2012; Heck et al. 2014; Mayberry et al. 2011; Porta et al. 2017; Russell et al. 2009). North American studies demonstrate that the protective factors associated with GSAs in schools include improved educational outcomes and attendance, increased visibility of supportive adults (Walls et al. 2010), and decreased reports of depression and health risk behaviours, such as drug and alcohol abuse (Heck et al. 2014). Furthermore, US research indicates that schools with GSAs are more likely to have clearer LGBTIQinclusive policies (Sadowski 2016). Thus, Stonefish and Lafreniere (2015) argue that GSAs play an important dual role in schools: providing educational benefits in areas of civics, health, and sexuality and relationships education, and enabling opportunities for student activism and community service.

GSAs are unique in that they are student-led and provide a "youth-driven context for the development of youth leadership, activism, and engagement in social change" (Russell et al. 2009, 892). Schindel $(2008,57)$ similarly frames GSA efforts as mobilising education; that is, students are "mobilizing people and resources directly within schools, as well as creating greater impact through their own increased mobility within these increasingly networked spaces." However, some research 
suggests that little in the way of social activism or policy reform has resulted from the formation of GSAs in the US, fuelling arguments that GSAs act merely as social clubs and safe spaces, that are largely depoliticised (Fingerhut 2011; Mayberry et al. 2011). In addition, critics note several barriers to GSA membership that problematise its political potential, including concern that GSA membership will 'out' closeted students to their heterosexual peers (Mayo 2013,2) and the lack of racial diversity and intersectional approaches in GSAs (Poteat et al. 2016). Stonefish and Lafreniere $(2015,17)$ counter this, arguing that the mere presence of GSAs in the heteronormative space of the school is political. Mayberry et al. (2011) also acknowledge that in order for more significant social and political change to arise from GSAs, social connections and bonding as a group must occur first.

Sadowski (2016) notes that teachers and school staff can play a useful role in the administration and facilitation of GSAs, equipping students with the skills they need to advocate for equity and social change. Beyond school-level programs and policies, teachers themselves play a key role in establishing inclusive school cultures, and they can function as the critical nexus between broad school-level supports and individual student outcomes (Swanson and Gettinger 2015, 331). Despite the importance of teachers as sources of support, most research examines the effects of anti-bullying policies, GSAs, and training programs by examining perceptions of students, rather than measuring direct effects on teachers' attitudes and behaviors. North American research provides insights into how GSAs influence staff approaches to LGBTIQinclusive practice and whole-school cultures. For instance, Swanson and Gettinger (2015) found that US teachers' willingness and ability to support LGBTIQ students increased with the presence of a school GSA. Similarly, Mayo (2013) observes that the active role of multiple staff in one US high school GSA increased student perceptions of safety and inclusion. The need for improved professional development to prepare staff to assist with GSAs is also well-established in the international literature (see Greytak et al. 2013).

\section{Theoretical Framework: Queer Theory, Neoliberalism, and Homonormativity}

An exhaustive overview of queer theory and neoliberalism is beyond the scope of this paper and is undertaken elsewhere (Jagose 1996, see also De Lauretis 1990; Epstein 
1998; Fuss 1991; Seidman 1997). However, in this section we will briefly outline some of the key concepts in order to contextualise contemporary understandings of sexuality and collective identity politics discussed in this article. Queer theoretical approaches are critical of the notion of an essential or innate gendered, sexual self. Instead, queer theorists draw from constructionist traditions to argue that gender, sexuality, and identity are created and reproduced through social interaction and performance (see Butler 1990; Weeks 2003). From these perspectives, the process of 'coming out' as LGBTIQ is less of a realisation of essential truth than a process of identity construction and a narrative ordering of subjective reality (see Weeks 2003). Therefore, queer theory intentionally destabilises identity categories.

Queer perspectives on sexuality and identity have drawn sustained critiques. The emergence of queer theory intersected with critical debates in gay and lesbian communities around identity, naming, and group membership. Scholars and activists questioned: "if gay (and man) and lesbian (and woman) are unstable categories, what happens to sexuality-based politics?" (Gamson 1995, 399). Bersani (1995) argues that the use of "queer" as an umbrella term for a range of non-normative sexualities and genders has a "de-gaying" effect, or a "liberal pluralism notorious for its capacity for co-option and depoliticisation" (Jagose 1996, 112). In response, Butler $(1990,148)$ argues that "the deconstruction of identity is not the deconstruction of politics, rather it establishes as political the very terms through which identity is articulated."

Drawing on queer theory, over the last three decades scholars from a range of fields have considered how neoliberalism has influenced sexuality and identity politics (see Brown 2012; Duggan 2002). Neoliberalism has been referred to as "shorthand for an array of complex economic, political, and cultural dynamics" (Grzanka et al. 2016, 300). While much of the theorising situates neoliberalism as a political theory based on free market economics (e.g. Harvey 2005), other scholars argue that neoliberalism has much broader social implications (e.g. Chen 2013). Rose (1999) demonstrates how, under neoliberalism, citizen-subjects are positioned as self-governing individuals who are responsible for their own individual choices, while state responsibility for social provision is withdrawn and privatised. Following this conceptualisation, in this article, we refer to neoliberalism as the constellation of practices by which the state influences individual behaviours through self-discipline 
and surveillance, with a focus on individualism (over collectivity) and privatisation of "public issues" (Grzanka et al. 2016, 298).

Feminist and queer scholarship illuminates how neoliberal ideologies transform gender and sexuality politics. Neoliberal ideologies implore people to move away from collective identities and to instead construct their own individualised, but apolitical and private, sexual identities (see Adams et al. 2014; Coleman-Fountain 2014; Hegna 2007). Critics of queer theory argue that both queer deconstructionism and neoliberal anti-identity politics share a similar rejection of collective identity that potentially stymies further collective rights-based activisms (Grosz 1995, 249-250). Several British and US scholars show how neoliberalism shapes contemporary LGBTIQ rights agendas in this way by shifting the focus from politicised collective identity-based action to calls for assimilation and individualised rights and freedoms (Duggan 2002; Richardson 2005). This has been referred to as a post-gay shift, with several North American, British, and Australian scholars documenting a decline in LGBTIQ-specific venues, services, and social scenes, in favour of mainstreaming or assimilation into dominant cultures (see Lea et al. 2015). Ghaziani (2011, 112-113) notably observes post-gay rhetoric among US LGBTIQ college student groups, with language shifting from collective identity groups (e.g. "gay, lesbian, and bisexual alliance," "gay-straight alliance," "LGBT support group") to more abstract, arguably less political language ("Pride Collective" "Ally Network").

Duggan $(2002,179)$ similarly describes this shift as the "new homonormativity," a paradigm where privileged "mainstream" (white, urban, middle-class, cisgender, monogamous) gay men and lesbians are positioned as "ordinary, normal citizens" who "do not contest dominant heteronormative assumptions and institutions, but uphold them while promising the possibility of a demobilised gay constituency and a privatised, depoliticised gay culture anchored in domesticity and consumption." Thus homonormativity has been used to describe "the emergence of a central power dynamic among 'queers' whereby neoliberal capitalism, patriarchy, colonialism and racism worked to empower some queer subjects and further marginalise others in the assimilation process" (Podmore 2013, 264). As an expression of the sexual politics of neoliberalism, homonormativity reduces the political importance of sexual identity labels, instead emphasising individuality, freedom, and choice. Homonormativity 
correlates with the concept of the post-gay shift insofar as it positions sexuality as a private, individualised experience that no longer holds political salience in the contemporary neoliberal context.

While homonormativity is a useful concept for analysing how white, middle-class, cisgender, able-bodied queer subjects experience rights and citizenship in an allegedly post-gay era, the term is not without its critiques. Brown (2012) argues that, like neoliberalism, homonormativity has come to be used as a homogenous global entity, disregarding the very specific context in which the concept originated and failing to allow possibility for change. Gorman-Murray (2017) takes issue with Duggan's (2002) theorising of homonormativity being centred on a critique of queer domesticity, which he argues unfairly negates many LGBTIQ people's links to home. Podmore (2013) similarly observes that much theorising of homonormativity establishes new false dichotomies between "normalised" and "radical" queers (see also Oswin 2008). Like Brown (2012), Gorman-Murray (2017) also argues that the US-centric framing of homonormativity limits its theoretical possibilities in other contexts, demonstrating this through his work on Australian queer domesticity.

As Gorman-Murray (2017) outlines, Australian research in this area is limited and, to our knowledge, no Australian studies explore the implications of homonormativity for LGBTIQ student groups. To address these knowledge gaps, this article will examine whether and how Australian teachers and school staff involved with LGBTIQ student support groups (GSAs or 'diversity groups') reproduce homonormative discourse through neoliberal diversity efforts.

\section{Method}

This article reports on data that was collected as a part of an interpretive qualitative study (Cohen, Manion and Morrison 2007) that investigated teacher and school staff understandings of LGBTIQ-inclusive education practices in Tasmania, Australia during 2017-2018 (see Grant et al. 2018). Participants were recruited through purposive sampling methods (Sekaran 2003) assisted by a local LGBTIQ organisation. The research team was provided with a list of schools who had accessed services from the LGBTIQ organisation (e.g. resource requests, referrals, professional 
development). The principals of these schools nominated relevant staff who were then invited to participate in the study. The study received ethical approval from the researching institution (H0016908) and the Department of Education (2017-44).

Data collection involved semi-structured interviews using an interview guide based on the literature and key research objectives. During interviews, participants were invited to share their experiences supporting LGBTIQ students, their understandings of school and department policy, and their professional development needs. Interviews were audio-recorded and transcribed verbatim with consent. Data have been de-identified and pseudonyms are used for staff and their schools.

Sixteen staff members from six Tasmanian State Government high schools participated in the study. Two of the schools were senior secondary only, each with approximately 1000 students. Three were high schools (years 7-10), with varied student numbers ranging between 200 and 700 students. One school offered education across years 7-12 and had approximately 200 students. All schools were comprised of predominantly caucasian, English speaking student and staff cohorts. Participants were class teachers $(n=7)$, social workers and school psychologists $(n=5)$, school nurses $(n=3)$, and school leadership ( $n=1)$ who had been working at their current schools for an average of 4.7 years. The majority of participants were women $(n=12)$ between the approximate ages of 25-60. Two participants identified themselves as members of the LGBTIQ community. While demographic data was not collected, at interview all participants identified as white, middle-class Australians. This lack of racial diversity one limitation of this study resulting in part from sampling techniques (see Babbie 2014, 200-201) and the well-documented under-representation of people of colour in the Tasmanian teaching profession (Lambert, Burnett \& Lebhers 2016).

Data were analysed based on an adapted Grounded Theory analytical approach (see Corbin and Strauss 2015). Authors 1 and 2 first analysed the data by inductive coding, surface reading transcripts and taking note of any striking words or phrases arising from the data using NVivo's annotate function. Once common themes were identified, thematic nodes were created in NVivo and relevant data was coded to those nodes. Initial themes identified included discussion of GSAs or student groups broadly. Further analysis revealed sub-themes of active and inactive student groups. 
To ensure the validity of this thematic analysis and inter-coder reliability of the coding system, Authors 2 and 3 conducted additional analyses and provided critical feedback on the initial interpretation of the data, including observation of a third subtheme of event-based initiatives.

\section{Findings}

GSAs or student diversity groups were a common topic in interviews, with school staff frequently mentioning the existence of these groups as an example of their school's inclusivity. All staff demonstrated an awareness of GSAs at their schools, with four participants facilitating their school's GSA, and four reporting an interest in being more actively involved in the future. Our analysis of teachers and staff accounts identified three distinct types of GSA function in Tasmanian high schools: singular event-based initiatives; inactive or poorly-attended groups; and active, well-attended groups.

\section{Inclusion for all: Singular event-based approaches to 'celebrating diversity'}

Several participants described their schools' student-led diversity and inclusion initiatives as being based around singular events such as Wear It Purple Day (see Beasy and Grant 2018) and Harmony Day. In line with LGBTIQ-inclusive practice literature (Sadowski 2016), visible demonstrations of inclusion are important for communicating a message of acceptance to students. However, in the neoliberal Australian education context both staff and students position LGBTIQ-inclusion in generalised terms, emphasising diversity and inclusion for everyone. This is reflected in the more common use of the term "diversity groups" among our participants, in contrast with the US term gay-straight alliances. Here we explore how two schools implicitly reproduced homonormative discourses by incorporating LGBTIQ-inclusion into broader celebrations of diversity. As we will argue, although well-meaning, these generalised celebrations of diversity create an illusion of equality, without explicitly addressing the continued structural oppression of

When asked what their schools do to promote LGBTIQ-inclusivity, participants frequently mentioned celebratory events and fundraisers. For example, Rosalie, a 
school nurse at Banksia High School, supervised a group of student leaders planning their Wear It Purple day event, a celebration to promote inclusivity and raise awareness about homophobic bullying:

Yeah, so we made purple popcorn and we had a cake, and we cut the cake in celebration of inclusion in our school.And then we had face painting, and free food, and they all wore bright and colourful purple and rainbow colours for the day, it was great.

Karla, a teacher at Newdegate High School, shared a similar account of her school's Harmony Day celebration:

We've got Harmony Day next week. Whenever we do Harmony Day, we do cultural food, right? Which is fine, but Harmony Day is not just about different cultures, it's about harmony, together. All we'd need to do is get the rainbow banner up and just give out coloured cool pops or something, icy poles, you know what I mean?

As evident from the staff members' accounts, singular student-run events took the place of regular, safe spaces for LGBTIQ students as neither school had a wellestablished GSA. Both events incorporated LGBTIQ-inclusion into a broader narrative of harmony and diversity. This emphasis on a generalised approach to inclusivity could be interpreted as a progressive, intersectional stance. However, expanding the purpose of an LGBTIQ student support group to focus generally on diversity arguably reflects a neoliberal positioning of identity and difference. Because neoliberalism emphasises individuality, shared collective identities are often reduced to similar 'lifestyles' or 'choices,' rather than any more innate or structural shared experiences. In this context, broadening the LGBTIQ support group de-emphasises the specific shared experiences of homophobia/biphobia/transphobia, to focus instead on how 'everyone's different.' Such generalised framings of seeking 'equality for all' can erase specific inequalities and obscure groups who are complicit or privileged by those inequalities. Bell and Hartmann $(2007,906)$ describe the processes through which organisations convert politicised discussions of equity into "happy talk". Participants' reflect this happy talk through their generalised approaches to inclusion 
as 'celebrating diversity.' Here, school discussions of diversity and inclusion conjure an "illusion of equality" by focusing on how "everyone's different," while effectively ignoring how those differences intersect with structures of power and oppression - the purpose of an intersectional approach (Ahmed 2012, 71). In these framings, LGBTIQinclusion is promoted because it allows a school to promote itself, creating a surface or illusion of happiness (Ahmed 2012, 72).

Approaching LGBTIQ-inclusion through celebratory events can also be interpreted through an Interest Convergence framework. Interest Convergence is a theoretical tool stemming from Critical Race Theory (Bell 1980). It is used to describe a situation in which minority rights are only gained when the interests of the marginalised people converge, or align, with the mainstream interests of the elite (Milner 2008). Interest Convergence is predicated on a sense of "my loss-your gain," where supporting minorities is seen as a "loss" for elites, so diversity and inclusion measures will only be supported when elites believe there is something to gain (Milner 2003, 333-334). In this respect, neoliberal diversity and inclusion efforts are strongly influenced by a capitalist marketisation ethos, as equity is commodified and measured in terms of its cost-benefit ratio. In this context, framing LGBTIQ-inclusion through singular celebratory events that include everyone benefits dominant groups as these events foster a "feel good politics" of cultural enrichment through diversity while not requiring any critical work of those in positions of privilege (Ahmed 2012, 66). In line with Ahmed (2012), both Rosalie and Karla's accounts show how their schools' celebrations positioned diversity as appealing, something enjoyable and sweet to be consumed, through the metaphor of cakes, coloured popcorn, and icy poles. Thus generalised celebrations of diversity can be interpreted as an act of neoliberal 'equity consumerism,' in keeping with neoliberalism's consumer capitalist framings of 'choice' and the 'feel good politics' of inclusion.

\section{“Too Lazy To Come Out”: Inactive Diversity Groups}

The difficulties experienced by teachers and school staff in establishing and maintaining a GSA at their school was consistently discussed by participants. Some participants gave examples of active GSAs that previously operated in their schools but had, by the time of the research, become less-active. Jodi, a social worker at 
Newdegate High School, for example, reflected on an active GSA she previously supported at her school. Jodi described the group of 20 students as "dynamic gogetters" who wanted to agitate for change. Within few years, however, the GSA had become inactive since these particular students had graduated from the school:

They just don't want to be part of a group, so that is the thing that I've noticed over the last four years. The group work for me here is not working, it doesn't matter how many times I send out every fortnight the Home Group News. Maybe I'll get phone calls or emails and then they'll come and see me, but a lot of times its one on one. Sometimes they have [formed] their own thing, so they feel supported and they are collected and connected, so maybe they don't feel like they have to be in a group.

Poor student attendance at her school's GSA over time led Jodi to believe that LGBTIQ young people do not want to participate in collective identity based groups at school. Similarly, some other participants also questioned whether LGBTIQ young people in contemporary Australian schools need a dedicated support group:

There have been a number of attempts to start groups but the thing there is that they can't come from teachers, that has to come from the students - I guess maybe they don't feel the need, because we haven't been able to sustain a group. (Donna, teacher, Onslow High School)

I think they're getting more open, especially we've got a couple of kids now, and they're like "I don't care. They can just accept me for who I am". They mightn't come [to the GSA], but they know it's there, and they know that the school supports it, I think that's what makes them aware. (Rosalie, nurse, Banksia High School)

The ones that are outwardly gay, I think because they've been outwardly gay since they were late primary school even, they... I mean, they still feel stigma, 
but because they're so out, there isn't... there's not as much need for a special group. (Helen, nurse, Southside High School)

These accounts reflect participants' shared belief that students are not interested in joining collective identity-based groups at school. While this demonstrates the extent to which LGBTIQ students are also under the influence of neoliberalism (see Grant and Nash 2019, in-press), such beliefs place the onus on students for establishing and maintaining school-based GSAs and position students as the cause of inactive, poorlyattended or non-existent groups. In doing so, the whole-school culture and broader structural conditions (see Grant and Nash 2018) that may influence students' decisions to participate in these groups are neglected or ignored. This attribution of responsibility onto LGBTIQ young people by participants fails to account for the socio-cultural context of the neoliberal identity. Regarding young people as "too lazy to come out" plays into the hand of neoliberal constructions of identity as private and of the individual's own making. Participant accounts suggest that school staff are conflating students' lack of engagement with GSAs as a lack of interest in opportunities for being part of collectivities that value identity, and in opportunities for creating positive change for minority identities in their school. As Grant et al. (2018) argue, policies and practices implemented at the whole-school level are critical in cultivating inclusive school cultures that support LGBTIQ students in schools. Accordingly, failure to recognise systemic, whole-school conditions that may be contributing to inactivity within school-based GSAs may limit schools' capacities to provide inclusive learning environments for LGBTIQ students.

\section{Active Groups}

In line with previous research (e.g. Sadowski 2016), participants involved in active GSAs spoke at length about the value they saw in having a dedicated space for LGBTIQ students and allies:

Last year the group was massive. They met two days in the week. One day in the week, they had a more formal meeting, where they got plans rolling. And then on the other day was just really a get-together day. So my role was more like just being a friend, and walking around and chatting to different groups. And occasionally I would 
try to get them to talk about gender diversity or about a bunch of things... (Helen, school nurse, Southside High School).

I started our LGBTIQ group up at the school, and it's quite a large population. Our first meeting had 20-something people come. We've sort of got to roll with what [the students] want, so, this year, we're doing more planning activities, whereas last year it was just more of a safe space. (Amy, school nurse, Thornton High School).

The first time we started [the group], it was more of a support group for the LGBTIQ community. And that was really important for students to get together, and good for me to be able to touch base to see what's going on in the school, and [find out if] there are any issues. So, they made posters to advertise Wear It Purple Day, and that sort of thing. (Rosalie, school nurse, Banksia High School).

For these participants ,GSAs were seen as a safe place where students could "get together," with potential for more structured activities. At a glance, these active groups reflect critiques that in neoliberal schooling environments, GSAs can act merely as social clubs, without any clear political or activist focus (Fingerhut 2011; Mayberry et al. 2011). However, when asked about group activities in and around the school, Rosalie offered an example of poster making, noting how students produced awareness-raising posters about LGBTIQ issues. The act of making posters for display around the school signifies students' desire to create and communicate a collective identity and in effect, troubles neoliberal assertions of identity as private and individualised. The students created posters as an invitation for others to be a part of the collective identity of the group. At the same time, the posters acted to solidify and legitimate the LGBTIQ identity outside of the dominant heteronormative practices of the school.

While GSAs can promote social justice activism, queer pedagogy, and critical education practices, we observed that both hetero- and homonormative discourses could act as containment strategies (see Mills 1996) to prevent more politicised activities even in schools with well-established diversity groups. For example, in Helen's account below, the Southside High GSA received less support when it shifted from being a social group to wanting to engage in more explicit LGBTIQ activism, in 
the form of an awareness-raising presentation on homophobia and transphobia at school:

the whole thing got watered down so much, it didn't happen because the HPE staff, or others, didn't feel competent to deliver it, and what the kids in the diversity group had wanted to say got watered down to an extent where they weren't happy with it, and then the whole thing sort of just got put aside as too difficult. Which is a terrible shame and very frustrating. (Helen, School Nurse, Southside High School)

In Helen's account the GSA at her school had remained largely depoliticised and had acted more as a safe space for LGBTIQ students and allies than a political mechanism. Yet, as Helen describes, when students pushed the boundaries of their homonormative activities such as politicising ideas of gender and sexuality and directly challenging the heteronormativity of school culture, practices became constrained and bureaucratised. This GSA activity contravened homonormative discourse in the sense that it took a more critical and explicit approach to challenging structural discriminations at the school, rather than performing 'acceptable' queerness in the form of an apolitical social group. Here, challenging previous institutional understandings of what was relevant for staff and students to know about LGBTIQ identities was "put aside as too difficult." Mills (1996) suggests that containment discourses operate in schools to maintain the orderly running of the institution. The "watering down" of the work being done by the students is an example of teachers and schools containing the political agendas and practices of GSAs.

\section{Discussion}

The work of the students and staff involved in the GSAs in this study demonstrate the valuable role they play in schooling communities. GSAs provide LGBTIQ students with an opportunity for a collective and legitimated identity, promote health and wellbeing, and highlight the supports available at school (Sadowski 2016). However, the GSAs in this study were found to operate within a homonormative paradigm that does not challenge heteronormative assumptions and institutional structures.Even within schools with active GSAs, politicised activities designed to disrupt heteronormativity were often 'watered down' or 'put aside as too difficult.' 
Institutional pressures on staff and students were found to restrict or control the messages about LGBTIQ identities that were promoted within the school environment. As such,the GSAs were depoliticised and tended to encourage a model of inclusion based on 'sameness' or assimilation with dominant cultures (Duggan 2002). This echoes Fingerhut (2011) and Mayberry et al. (2011) critique when they highlight the potential of GSAs to draw attention away from a structural reform in school policy and practice.

By deploying the homonormative language of 'diversity' and 'harmony' (see Ghaziani 2011), coupled with party food and activities, singular event-based inclusive strategies evoked a sense of carnivalesque (see Ravenscroft and Gilchrist 2008), or temporary, hedonistic practices that transcend the every day. This raises questions as to whether such singular events tangibly promote whole-school inclusive cultures that are sustainable beyond the space and timeframe of the event itself. Furthermore, who do these events benefit? While staff reported an improved sense of LGBTIQ-visibility and cultural wellbeing among students as a result of these events, previous research demonstrates the need for ongoing structural supports (e.g. inclusive practice policies, school leadership, professional development) to mainstream LGBTIQ-inclusion in schools (Grant et al. 2018; Swanson and Gettinger 2016). Therefore, we argue that, while celebratory days are an important way to build inclusive school environments, the often neoliberal framing of these events fails to address the structural barriers LGBTIQ students face and does not produce inclusive whole-school cultures on their own.

Neoliberal narratives were also evident in how students' (dis)engagement with GSAs was perceived by school staff. Participants' comments suggest that homonormative discourses may be internalised by school staff, reflected by the shared assumption that students in a post-gay era no longer need identity-based support groups. Some participants in this study asserted that today's "outwardly gay" students are more resilient than past LGBTIQ young people who had participated in GSAs at their schools. Participants did not consider the depoliticised contexts of GSAs as cause of disengagement from, or lack of engagement with, the school GSA. Instead, participants tended to take up neoliberal narratives and responsibilise students as the cause for lack of involvement through narratives of individuals as "lazy." Such 
approaches deny the need for continued collective identity-based advocacy and activism in schools and problematically dismiss the ongoing challenges for LGBTIQ young people in schooling contexts. Arguably, neoliberal narratives act to reinforce homonormative agendas, provide teachers with a lens in which to 'see' student (in)action through and at the same time, reduce student capacity for resistance.

Active GSAs were found to operate tenuously within a landscape of heteronormativity, demanding homonormative expressions of diversity. As Mills (1996, 318) observes, schools are inscribed with a chain of command structure and "challenges to this structure are perceived as a challenge to the legitimacy of the organisational principles inherent in this institutional model". A tension exists here in schools maintaining heteronormativity and at the same time, fostering students critical thinking and agency. So while GSAs provided a safe space for students to come together, the activities that students undertook were largely advancing homonormative or assimilationist agendas within the schools, which facilitators tended to encourage. Without expressions or activities that trouble heteronormativity, apolitical ideas of identity tended to be reproduced. This raises questions as to what supports are available to students in undertaking the critical work required to disrupt structural inequalities when political work is not encouraged or supported through GSAs.

While homonormative discourses were found to be productive in enabling the existence of GSAs, they do not seek to challenge hegemonic interests and encouraged diverse gender and sexuality expression to occur in the shadow of heterosexual or cisgender identities. While we problematise the apolitical operations of GSAs in this study, we also acknowledge the prevailing benefit of safety enabled through their existence in school settings. Yet, we question whether homonormative discourses enacted in GSAs enable comfortable/tolerant inclusion of LGBTIQ identities and prevent the radicalisation of policy and practice required to create conditions that enable LGBTIQ students to flourish. Building on the findings of this study, we encourage further Australian education and sexualities scholarship to further consider the impact of homonormativity on inclusive education practices, particularly student diversity groups. 


\section{References}

Adams, J., V. Braun, and T. McCreanor. 2014. “'Aren’t labels for pickle jars, not people?' Negotiating identity and community in talk about 'being gay."' American Journal of Men's Health 8 (6): 457-469.

Ahmed, S. 2012. On being included: Racism and diversity in institutional life. Durham: Duke University Press.

Baak, M. 2019. "Racism and othering for South Sudanese heritage students in Australian schools: Is inclusion possible?.” International Journal of Inclusive Education 23 (2): 125-141.

Babbie, E. 2014. The Basics of Social Research Sixth Edition. Belmont: Wadsworth.

Beasy, K. and R. Grant. 2018. "More than just lip service: Done right, awarenessraising days can pack a punch.” The Conversation, 31 August 2018. Accessed 18 December 2018. https://theconversation.com/more-than-just-lip-service-done-rightawareness-raising-days-can-pack-a-punch-101661

Beemyn, B. 2003. "The silence is broken: A history of the first lesbian, gay, and bisexual college student groups." Journal of the History of Sexuality 12 (2): 205-223.

Bell, D.A. 1980. "Brown v. Board of Education and the interest-convergence dilemma." Harvard Law Review 1: 518-33.

Bell, J.M. and D. Hartmann. 2007. "Diversity in everyday discourse: The cultural ambiguities and consequences of 'happy talk.'” American Sociological Review 72: 895-914.

Bersani, L. 1995. Homos. Cambridge: Harvard University Press. 
Brown, G. 2012. "Homonormativity: A Metropolitan Concept that Denigrates

‘Ordinary’ Gay Lives.” Journal of Homosexuality 59 (7): 1065-1072.

Butler, J. 1990. Gender Trouble. New York: Routledge.

Čeplak, M. M. 2013. "Heteronormativity: School, ideology, and politics.” Journal of Pedagogy/Pedagogický Casopis 4 (2): 162-187.

Chen, E. 2013. “Neoliberalism and popular women's culture: rethinking choice, freedom, and agency." European Journal of Cultural Studies 16 (4): 440-452.

Clarke, P. and B. MacDougall. 2012. "The case for gay-straight alliances (GSAs) in Canada's public schools: An educational perspective." Education Law Journal 21 (2): 143.

Cohen, L., L. Manion, and K. Lawrence. 2007. Research methods in education (6th ed.). Milton Park: Routledge.

Coleman-Fountain, E. 2014. "Lesbian and gay youth and the question of labels." Sexualities 17 (7): 802-817.

Corbin, J and A. Strauss. 2015. Basics of Qualitative Research: Techniques and Procedures for Developing Grounded Theory Fourth Edition. Thousand Oaks: Sage.

De Lauretis, T. 1991. Queer theory: Lesbian and gay sexualities. Bloomington: Indiana University Press.

Dragowski, E. A., P.C. McCabe, and F. Rubinson. 2016. "Educators' reports On Incidence Of Harassment And Advocacy Toward LGBTQ Students." Psychology in the Schools 53 (2): 127-142. DOI: 10.1002/pits.21895

Duggan, L. 2002. "The New Homonormativity: The Sexual Politics of Neoliberalism." in R. Castronovo and D. D. Nelson (Eds) Materializing Democracy: Toward a Revitalized Cultural Politics. Durham: Duke University Press: 
Elia, J. P., and M. J. Eliason. 2010. "Dangerous omissions: Abstinence-only-untilmarriage school-based sexuality education and the betrayal of LGBTQ youth." American Journal of Sexuality Education 5 (1): 17-35.

Epstein, S. 1998. "Gay politics, ethnic identity: The limits of social constructionism." In Nardi, P.M., B.E. Schneider and K. Plummer (Eds) Social perspectives in lesbian and gay studies: A reader. New York: Routledge: 134-59.

Faas, D., A. Smith and M. Darmody. 2018. "Children's agency in multi-belief settings: The case of community national schools in Ireland." Journal of Research in Childhood Education 32 (4): 486-500.

Fetner, T., A. Elafros, S. Bortolin, and C. Drechsler. 2012. "Safe spaces: Gay-straight alliances in high schools." Canadian Review of Sociology/Revue canadienne de sociologie 49 (2): 188-207.

Ferfolja, T. and K.H. Robinson. 2004. "Why anti-homophobia education in teacher education? Perspectives from Australian teacher educators." Teaching Education 15 (1): 9-25. DOI: 10.1080/1047621042000179961

Fingerhut, A. W. 2011. "Straight allies: What predicts heterosexuals' alliance with the LGBT community?” Journal of Applied Social Psychology 41 (9): 2230-2248.

Flores, G. 2012. "Toward a more inclusive multicultural education: Methods for including LGBT themes in K-12 classrooms." American Journal of Sexuality Education 7 (3): 187-197.

Fuss, D. 1991. Inside/Out: Lesbian Theories, Gay Theories. London: Routledge.

Gamson, J. 1995. "Must identity movements self-destruct? A queer dilemma.” Social Problems 42(3): 390-407. 
Gansen, H. M. 2017. "Reproducing (and disrupting) heteronormativity: Gendered sexual socialization in preschool classrooms." Sociology of Education 90 (3): 255272.

Ghaziani, A. 2011. "Post-Gay Collective Identity Construction.” Social Problems 58 (1): 99-125.

Gorman-Murray, A. 2017. "Que(e)rying homonormativity: The everyday politics of lesbian and gay homemaking." in Pilkey, B., R. M. Scicluna, B. Campkin, and B. Penner (Eds) Sexuality and Gender at Home: Experience, Politics, Transgression. Bloomsbury: London: 149-162.

Grant R., K. Beasy, S. Emery, and B. Coleman. 2018. "Beyond Safety?: Teachers and school staff approaches to LGBTI-inclusion in Tasmanian Schools." International Journal of Inclusive Education. doi/full/10.1080/13603116.2018.1555866.

Grant, R. and M. Nash. in-press. "Homonormativity or Queer Disidentification? Rural Australian Bisexual Women's Identity Politics.” Sexualities.

Grant, R. and M. Nash. 2018. "Educating Queer Sexual Citizens? A qualitative feminist exploration of bisexual and queer young women's sex education in Tasmania, Australia." Sex Education. DOI: 10.1080/14681811.2018.1548348.

Greytak, E.A., J.G. Kosciw, and E.M. Diaz. 2009. Harsh Realities: The Experiences of Transgender Youth in Our Nation's Schools. New York: Gay, Lesbian and Straight Education Network (GLSEN).

Grosz, E. 1995. Space, Time and Perversion: the politics of bodies. Sydney: Allen and Unwin.

Grzanka, P.R., E.S. Mann, and S. Elliott. 2016. "The neoliberalism wars, or notes on the persistence of neoliberalism." Sexuality Research and Social Policy 13: 297-307. 
Harvey, D. 2005. A Brief History of Neoliberalism. New York: Oxford University Press.

Heck, N.C., N.A. Livingston, A. Flentje, K. Oost, B.T. Stewart, and B.N. Cochran. 2014. "Reducing risk for illicit drug use and prescription drug misuse: High school gay-straight alliances and lesbian, gay, bisexual, and transgender youth." Addictive Behaviors 39 (4): 824-828.

Hegna, K. 2007. "Coming out, coming into what? Identification and risks in the 'coming out' story of a Norwegian late adolescent gay man." Sexualities 10 (5): 582602.

Hillier, L., T. Jones, M. Monagle, N. Overton, L Gahan, J. Blackman and A. Mitchell. 2010. Writing Themselves In 3: The third national study on the sexual health and wellbeing of same sex attracted and gender questioning young people. Australian Research Centre in Sex, Health and Society: La Trobe University, Melbourne. Accessed 18 December 2018. https://www.glhv.org.au/report/writing-themselves-3$\underline{\text { wti3-report }}$

Jagose, A. 1996. Queer theory: An introduction. New York: New York University Press.

Jones, T. and L. Hillier. 2013. "Comparing Trans-spectrum and same-sex attracted youth in Australia: Increased risks, increased activisms.” Journal of LGBT Youth 10 (4): 287-307. DOI: 10.1080/19361653.2013.825197

Jones, T., E. Smith, R. Ward, J. Dixon, L. Hillier, and A. Mitchell. 2016. "School experiences of transgender and gender diverse students in Australia." Sex Education 16 (2): 156-171. DOI: 10.1080/14681811.2015.1080678

Kampler, B. and C. Connell. 2018. "The post-gay debates: Competing visions of the future of homosexualities." Sociology Compass, e12646. DOI: $10.1111 / \mathrm{soc} 4.12646$ 
Kosciw, Joseph G., Neal A. Palmer, Ryan M. Kull and Emily A. Greytak. 2013. "The Effect of Negative School Climate on Academic Outcomes for LGBT Youth and the Role of In-School Supports.” Journal of School Violence 12 (1): 45-63. DOI: $10.1080 / 15388220.2012 .732546$

Lapointe, A. 2017. “'It's not Pans, It's People': Student and Teacher Perspectives on Bisexuality and Pansexuality." Journal of Bisexuality 17(1): 88-107. DOI: $10.1080 / 15299716.2016 .1196157$

Lapointe, A. 2015. "Queering the social studies: Lessons to be learned from Canadian secondary school Gay-Straight Alliances.” Journal of Social Studies Research, doi:10.1016/j.jssr.2015.07.004

Lapointe, A. 2014. 'Gay-straight alliance (GSA) members' engagement with sex education in Canadian high schools." Sex Education 14 (6): 707-717.

Lea, T., J. de Wit and R. Reynolds. 2015. “'Post-Gay' Yet? The Relevance of the Lesbian and Gay Scene to Same-Sex Attracted Young People in Contemporary Australia.” Journal of Homosexuality 62 (9): 1264-1285.

Liboro, R. M., R. Travers, and A. St. John. 2015. "Beyond the dialectics and polemics: Canadian Catholic schools addressing LGBT youth issues." High School Journal 98 (2): 158-180. doi:10.1353/hsj.2015.0000

Mathers, L.A., J.E. Sumerau, and R.T. Cragun. 2018. “The Limits of Homonormativity: Constructions of Bisexual and Transgender People in the Post-gay Era.” Sociological Perspectives 61 (6): 934-952.

https://doi.org/10.1177/0731121417753370

Mayberry, M., T. Chenneville, and S. Currie. 2011. "Challenging the sounds of silence: A qualitative study of gay-straight alliances and school reform efforts." Education and Urban Society 45 (3): 307-339. DOI:10.1177/0013124511409400 
Mayo, J.B. 2013. "Critical pedagogy enacted in the Gay-Straight Alliance: New possibilities for a third space in teacher development." Educational Researcher 42 (5): 266-275. DOI:10.3102/0013189£13491977

Miceli, M. 2005. Standing out, standing together: The social and political impact of gay-straight alliances. New York: Taylor and Francis.

Mills, M. 1996. “'Homophobia Kills': a disruptive moment in the educational politics of legitimation.” British Journal of Sociology of Education 17 (3): 315-326. DOI: $\underline{10.1080 / 0142569960170305}$

Milner, H.R. 2008. "Critical race theory and interest convergence as analytic tools in teacher education policies and practices." Journal of Teacher Education 59: 332-46.

Oswin, N. 2008. "Critical geographies and the uses of sexuality: deconstructing queer space.” Progress in Human Geography 32 (1): 89-103.

Peter, T., C. Taylor, and L. Chamberland. 2015. "A queer day in Canada: Examining Canadian high school students' experiences with school-based homophobia in two large-scale studies." Journal of homosexuality 62 (2): 186-206.

Podmore, J. 2013. "Critical commentary: Sexualities landscapes beyond homonormativity." Geoforum 49: 263-267.

Porta, C.M., E. Singer, C.J. Mehus, A.L. Gower, E. Saewyc, W. Fredkove, and M.E. Eisenberg. 2017. “LGBTQ youth's views on gay-straight alliances: Building community, providing gateways, and representing safety and support." Journal of School Health 87 (7): 489-497.

Poteat, V. P., N.C. Heck, H. Yoshikawa, and J.P. Calzo. 2016. "Greater engagement among members of gay-straight alliances: individual and structural contributors." American educational research journal 53 (6): 1732-1758. 
Ramussen, M. L. 2006. Becoming subjects: Sexuality and secondary schooling. New York: Routledge.

Ravenscroft, N. and P. Gilchrist. 2009. "Spaces of transgression: governance, discipline and reworking the carnivalesque." Leisure Studies 28(1): 35-49. DOI: $\underline{10.1080 / 02614360802127243}$

Richardson, D. 2005. “'Desiring Sameness?' The rise of a neoliberal politics of normalisation." Antipode 37 (3): 515-535.

Robinson, K.H., P. Bansel, N. Denson, G. Overden, and C. Davies. 2014. Growing Up Queer: Issues facing young Australians who are gender variant and sexuality diverse. Young and Well Cooperative Research Centre: Melbourne.

Robinson, K.H., and T. Ferfolja. 2002. "A Reflection of Resistance: Discourses of Heterosexism and Homophobia in Teacher Training Classrooms." Journal of Gay \& Lesbian Social Services 14 (2): 55-64. DOI: 10.1300/J041v14n02_05

Rose, N. 1999. Powers of Freedom: Reframing Political Thought. London: Cambridge University Press.

Russell, S. T., A. Muraco, A. Subramaniam, and C. Laub. 2009. "Youth empowerment and high school gay-straight alliances." Journal of youth and adolescence 38 (7): 891-903.

Sadowski, Michael. 2016. Safe Is Not Enough: Better Schools for LGBTQ Students. Cambridge, MA: Harvard Education Press.

Savin-Williams, R.C. 2005. The New Gay Teenager. Cambridge: Harvard University Press.

Schindel, J.E. 2008. "Gender 101 - Beyond the binary: Gay-straight alliances and gender activism." Sexuality Research and Social Policy 5 (2): 56-70. 
Seidman, S. 1997. Difference Troubles: Queering Social Theory and Sexual Politics. New York: Cambridge University Press.

Sekaran, U. 2003. Research methods for business: A skill-building approach (4th ed.). New York: John Wiley \& Sons.

Shannon, B. 2016. "Comprehensive for who? Neoliberal directives in Australian 'comprehensive' sexuality education and the erasure of GLBTIQ identity." Sex Education 16 (6): 573-585. DOI: 10.1080/14681811.2016.1141090

Slee, R. 2001. "Social justice and the changing directions in educational research: The case of inclusive education." International Journal of Inclusive Education 5 (3): 167177.

Stevens, L. and G. Wurf. 2018. "Perceptions of inclusive education: A mixed methods investigation of parental attitudes in three Australian primary schools." International Journal of Inclusive Education, doi.org/10.1080/13603116.2018.1464068

Stonefish, T. and K.D. Lafreniere. 2015. "Embracing Diversity: The Dual Role of Gay-Straight Alliances.” Canadian Journal of Education 38 (4): 4.

Swanson, K. and M. Gettinger. 2016. "Teachers' knowledge, attitudes, and supportive behaviors toward LGBT students: Relationship to Gay-Straight Alliances, antibullying policy, and teacher training." Journal of LGBT Youth 13 (4): 326-351.

Szalacha, L. 2004. "Educating Teachers on LGBTQ Issues.” Journal of Gay \& Lesbian Issues in Education 1 (4): 67-79, DOI: 10.1300/J367v01n04_07

Toynton, R. (2006). "'Invisible other' Understanding safe spaces for queer learners and teachers in adult education." Studies in the Education of Adults 38 (2): 178-194.

Waling, A. and J.A. Roffee. 2018. "Supporting LGBTIQ+ students in higher education in Australia: Diversity, inclusion and visibility." Health Education Journal, DOI: 0017896918762233. 
Walls, N. E., S.B. Kane, and H. Wisneski. 2010. "Gay-straight alliances and school experiences of sexual minority youth." Youth and Society 41 (3): 307-332.

Ward, R. 2017. “'I just want to be myself”: How we can challenge homophobia, transphobia, and racism in Australian schools." Journal of Intercultural Studies 38 (4): 469-479.

Weeks, J. 2003. "Necessary Fictions: Sexual Identities and the Politics of Diversity." In Weeks, J., J. Holland, and M. Waites (Eds.) Sexualities and Society: A Reader. Cambridge: Polity Press: 122-131. 